\title{
A Review on Need for a Caring Economics with Special Reference to Sri
}

\section{Lanka}

Divassini P. ${ }^{1}$ and Manjaree H. M. S. ${ }^{2}$

${ }^{1}$ Department of Accountancy, Faculty of Commerce and Management Studies, University of Kelaniya

${ }^{2}$ Faculty of Management and Finance, University of Colombo

1pdivassini@gmail.com, 22saradhikamanjaree@yahoo.com

\begin{abstract}
The aim of the survey is to find out the need of caring economics which focuses on the caring economic practices in the context of Sri Lanka. Basically, Caring Economics provides a genuine caring for people and nature as the uppermost priority in an economic system. The study contains a systematic literature review on caring economics that is urgently needed by policymakers and business leaders to foster personal, business, and national economic success. The conventional indicators of economic health in Sri Lanka such as unemployment rate do give absolute value of life-sustaining activities of household economy, unpaid economy, and natural economy. As the outcome of the study, it is found that there is a need for caring economics with the concern of rapidly changing technological changes and social conditions in Sri Lanka.
\end{abstract}

Keywords: Caring Economics, Change, Households, Need, Values

\section{Introduction}

All people have participated in the economy as consumers, many as workers and also as producers. Every day people make decisions that belong within the realm of economics. What to buy? What to make and sell? How many hours to work? People have paid taxes. They have saved their earnings in a bank account. All of these activities (and many more) belong to the realm of economics. Households and firms are the basic units of an economy and are concerned with the economic problem (Birchall, 2016). How best to satisfy unlimited wants using the limited resources that are available? As such, economics is the study of how society uses its scarce resources. Its aim is to provide insight into the processes governing the production, distribution and consumption of goods and services in an exchange economy.

${ }^{1}$ https://orcid.org/0000-0001-7665-2900

Kelaniya Journal of Management | 2017 | Special Issue | Page 13 
Economics as a science that studies the ways in which finite amounts of resources are allocated to an infinite number of wishes (Rougoor, Trip, Huirne, \& Renkema, 1998).

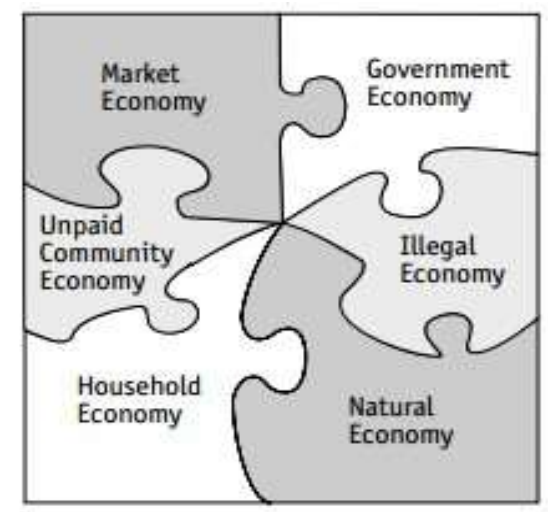

Figure 1: The New Economic Map

Source: Eisler (2007), The Real Wealth of Nations: Creating a Caring Economics

In the process of allocating resources among the unlimited needs and wants of human, at present it is questioning that just a quantitative aspects of human is sufficient to reach the optimal economic well-being. Essentially, Eisler (2007) stated that "Creating a caring economics invites to revisit the existing economic practices in the nations and emphasis on real need of change". Further he detailed that caring economics was trying to elaborate the economics in both quantitative, which is already existing and qualitative, caring and caregiving which need to be poured to the current economic system all over the nations.

Eisler (2007) was arguing on a gap in between economics and human life since people lives daily as employers, employees and consumers. Further, environmental problems, social problems and their focus on free markets or privatization verses central planning or government regulations are uplifted day by day, but not the human behavior on each economics. Therefore, there is a need to look the economics in a different way by concerning rapidly changing technological and social conditions. Hence this concept is highly emphasizing the new economic map which was focusing on six sectors namely; Household Economy, Unpaid Community Economy, Market Economy, Illegal Economy, Government Economy and finally Natural Economy need to be interconnected to each other. To build a new economic model, Nation must include the full spectrum of economic relations. 
Caring and empathy have to be suppressed and devalued to maintain the ranking of domination. The partnership system plays the vice versa role of domination in which it supports mutually respectful and caring relations. In their hierarchies' accountability and respect flow both ways rather than just from bottom up and social and economic structures are set up so that there are inputs from all levels (Eisler, 2007).The environmental and social implications may face, or sometime already facing by the community due to less concern on care and care giving. Further scientists have also warn that a "need " of a radical changes in practices and policies, if not would results in accelerating the global warming, risk of flood engulf the world's coastal cities and social impacts such as hunger and poverty. As the suggestion, the education system must "change" to ensure to have the quality of human capital needed for the post-industrial economy and the "need" of showing the government and business leaders the benefits of policies that support caring and care giving.

\section{Literature Review}

Economics comes from oikonomia which is the Greek word for managing the household- and a core component of households is caring and care giving (Eisler, 2007). But at present what a nation practice as economic models strangely ignore some of the most basic facts about human existence; rather corporate profits, international trade agreements, job outsourcing, employment figures, inflation etc. Research studies also have defined economics all about how people make choices (Becker, 1960) yet again proving the human decision making and the behavior need to be directly impact by the economy. But it is noted that even in the rich United States working parents are stresses because they have too little time to care for their children, and even well to do people find it hard to juggle work and family (Eisler, 2007).

Today, economic health is still measured by Gross Domestic Product (GDP). This measure pays no attention to poverty, hunger, or environmental degradation (Eisler, 2013). It does not give any symptom of the human and environmental damage caused by a large portion of the activities GDP includes as "productive" damage that is still clumped under the quaint rubric of "externalities" (Eisler, 2013). Later on researches also have studied the "need" of change and accordingly a research study has concluded that improved housing, work conditions, nutrition, health care, and reduced exposure to pathogens and poisons is insufficient. The specific mechanisms underlying the pervasive association between Socio Economic Conditions and health are surprisingly uncertain (Marmot M. G, et al., 1991). 
Moreover another study has also emphasis on human well-being, is a key factor under caring and care giving environment. Well-being should become a primary focus of policymakers, and that its rigorous measurement is a primary policy imperative. Well-being is defined as peoples' positive evaluations of their lives, includes positive emotion, engagement, satisfaction, and meaning (Seligman, 2002). Some other studies concluded that health will be a key issue under the current economy perspective (Marmot M. G, et al., 1991).

Children who born in household environments and in which mothers have little or no supportive culture. It was at greatest risk for abnormal cortisol profiles and associated health problems, because socio economic conditions influence family environment, they have consequences for child health that extend beyond direct material effects, because health in turn may affect an individual's social and economic opportunities, a cycle of poor health and low socio economic conditions influence may be perpetuated generation after generation (Flinn \& England, 1997).

\section{Methodology}

The old economics approaches are not capable of adapting to new circumstances in the nation and it is unsure of measuring the economics in a proper way. There is growing recognition of economics that as a nation actually, there is a high need of thinking about economics and society in a new way. How a nation should focus on the direction of extreme social, environmental, and economic challenges? What kind of tools do we need to shift from the industrial to the post-industrial talent era? How can build a more equitable and sustainable world? (Eisler, 2013).

The main objective of the study is identifying the contemporary understanding of economic activity in Sri Lanka, which pinpoints caring economics highlights the work of care and caregiving that occurs within households and is often unpaid. This paper is also focusing on the framework of caring economics that are urgently needed by policymakers and business leaders to foster personal, business, and national economic success(Ghosh, 2015).For this purpose, secondary data was collected from the Annual Reports - Central Bank of Sri Lanka (CBSL, 2017), statistics - Department of Census and Statistics, Sri Lanka (The Department of Census and Statistics, 2017) and data from the World Bank in Sri Lanka (The World Bank Group, 2017) for the time period starting from year 2006 to 2015. 


\section{Findings of the Study}

Sri Lanka is a lower middle-income country with a total population of 21 million people and a per capita income of USD 3,924 in 2015 (The World Bank Group, 2017). Sri Lanka's economy grew at an average of $6.4 \%$ in between year 2010 to 2015. Sri Lanka's economy has transitioned from an agricultural economy towards a more urbanized economy driven by services. In 2015, the service sector accounted for $62.4 \%$ of Gross Domestic Product (GDP), followed by manufacturing $(28.9 \%)$ and agriculture $(8.7 \%)$.

Among developing countries, Sri Lanka is frequently cited as a country which has successfully implemented the direct approach to raising economic welfare while still maintaining a respectable rate of economic growth. In recent years, it has been argued that the large social expenditures of the Sri Lankan government are the chief cause of its high standard of living as indicated by the long life expectancy, low infant mortality, and high level of literacy of the country's population (Bhalla \& Glewwe, 1986).

Further this research study has concluded that in a cross-country comparison, Sri Lanka emerges as a country with relatively high living standards in the late 1970s. The real question is that whether Sri Lanka has achieved high living standards at present? Some scholars may argue that yes, with an average growing rate, average per capita income, single digit inflation rate, high literacy rate etc. indicate the well- being of an economy. But at the same point of view, as Sri Lankan again we are questioning from ourselves does the above mentioned indicators really sounds good? If so why we are still struggling so much to live as a nation? This self - question impliedly create a gap in Sri Lankan economy.

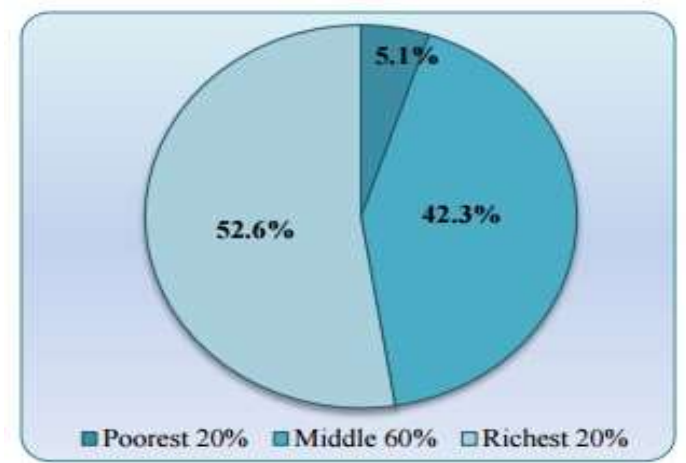

Figure 2: Share of household per capita income by household per capita income

Source: Household Income and Expenditure Survey - 2016, Department of Census and Statistics

According to Eisler (2007), she was elaborating how the financial wealth has been distributed in United States as $40 \%$ of financial quintiles - 2012/13 wealth among 1\% and 9\% of financial 
wealth among bottom $80 \%$, in which emphasis of unfair distribution. According to Statistics (2017), Figure: 2 shows the share of household per capita income by household per capita income quintiles where $52.6 \%$ among top $20 \%$ and $5.1 \%$ among bottom $20 \%$ from January to December 2016. It clearly shows the vicious of income distribution among one small island.

Even though the quantitative statistical shows the smoothness of the economy in Sri Lanka the real sound is when some are enjoying the skim of the things others are suffering from poverty and hunger while a gap is remaining which has not address so far by the authorized personals and institutions. As a nation, in the journey of developed, it is need to address human peaceful, mental conditions and human well- being of the country. In latter parts of the survey unemployment has been increased in all the categories and most critical part is educated individuals unemployment rate is increasing 2014 to 2015. This creates the unrest conditions of younger generation and high risk of violence. According to Eisler (2013), she has focused on the younger generation's massive unrest in both the developing and developed world due to rapid changes in job market and unstable world.

\begin{tabular}{|c|c|c|c|c|c|c|}
\hline Dnewployment Rate & 2010(a) & $2014(b)(e)(d)$ & $2012(b)(e)(d)$ & $2013(b)(c)(d)$ & $2014(b)(c)(d)$ & $2015(b)(c)$ \\
\hline \multicolumn{7}{|l|}{ By Groder } \\
\hline Male & 3.5 & 2.7 & 2.8 & 32 & 3.1 & 3.0 \\
\hline Female & 2.7 & 7.1 & 6.3 & 6.6 & 6.5 & 7.6 \\
\hline \multicolumn{7}{|l|}{ Hy Age Graups (Years) } \\
\hline $15-19$ & 20.3 & 155 & 18.9 & 18.8 & $21 \mathrm{~A}$ & 24.1 \\
\hline $20-29$ & 13.8 & 12.4 & 11.3 & 13.1 & 136 & 14.2 \\
\hline $30-39$ & 3.1 & 2.8 & 2.5 & 2.7 & 2.7 & 3.1 \\
\hline $\left.\begin{array}{l}40-49 \\
50 \text { and abave }\end{array}\right\}$ & 1.0 & 0.7 & 0.8 & 1.0 & 0.9 & 10 \\
\hline \multicolumn{7}{|l|}{ By Level of Education } \\
\hline Grade 5 and below & $\ldots$ & $\ldots$ & $\ldots$ & $\ldots$ & $\ldots$ & $\ldots$ \\
\hline Grades $6-10$ & 3.6 & 3.4 & 3.2 & 3.4 & 34 & 3,4 \\
\hline GCE (ONL) & 6.9 & 53 & 6.0 & 6.0 & 5.9 & 6.4 \\
\hline GCE (A/L) \& above & 11.6 & 9.1 & 3.6 & 8.7 & 82 & 9.2 \\
\hline Overall & 49 & 42 & 4.0 & 4.4 & 43. & 4.7 \\
\hline
\end{tabular}

Figure 3: Labour Force and Unemployment

Source: Department of Census and Statistics, Sri Lanka Socio-Economic Data, 2015

Apart from the financial indicators, the economy is consistent with all social and environmental aspects which lead to sustainable development. According to the above data analysis net forest cover of Sri Lanka for last 20 years has been displayed, and critical reduction of forest coverage can be seen accordingly. 
This would be identifying as a major issue of the country since the sustainability is questioning and by compromising future generation resources how a country exist for future. These ill practices definitely impact on increasing global warming, unexpected rains, soil erosion, contaminant water sources etc. Some may be surprised as how these above mentioned impacts would effect on an economy and does the policy makers really need to concern of above factors? Yes, polluted environment may create unhealthy individuals and this effect on the country productivity.

Hence, government need to invest on health care and medicine more and more as Sri Lankan government is responsible on welfare products to the country. Further soil erosion cause land slip which is yet again a cost to the economy and flood situations would ruin the economics as we experienced in last month as Sri Lankans.

Table 1: 2017 Sri Lanka flood and landside

\begin{tabular}{|l|l|}
\hline Date & May 2017 (Ongoing) \\
\hline Location & 15 Districts of Sri Lanka \\
\hline Cause & Flood and Landside \\
\hline Deaths & 224 \\
\hline Non - fatal injuries & 72 \\
\hline Missing & 78 \\
\hline Property Damage & $\begin{array}{l}2093 \text { houses fully and 11,056 } \\
\text { houses partially destroyed }\end{array}$ \\
\hline
\end{tabular}

Source: The Department of Census and Statistics - Sri Lanka, 2017

These all arguments of both the author and the reader is underlying a "need" of "change" to the prevailing economic system in Sri Lanka. Surprisingly the author is describing the status of United States, where equally match with the Sri Lankan economy. As Sri Lankan, most of nation lovers are seeking a solution for above gap which needs to change this pathogen. According to the findings, Sri Lankans need to re-adjust their mind set and the attitudes towards caring and care giving culture in which, this is the cure for the nation wound. 
Most of us aren't even aware that much of what we value or devalue and thus our economic system are based on a system of gendered values. As a result, the devaluation of caring and its real - life consequences for us all remains largely unrecognized (Eisler, 2007). It also can be critically evaluate the public behavior towards the victims of flood previous month, since public did a massive and most important actions at the time which was really required.

As Sri Lankans this is the best most evidence to show that our nation is turning towards the need of caring and care giving which is the prominent matter of "change" in the nation. As an essential guiding step towards a caring economic, it is proposed to develop an accurate system of economic bookkeeping which is suitable for Sri Lanka, since the mind sets of humans' already tent to be caring and a planned framework and one common appropriate system is also required.

\section{Discussion and Recommendations}

As per the current fiscal priorities, we see that policymakers always seem to find money for control and domination for prisons, weapons and wars. But we're told there is no money for caring and caregiving for activities such as caring for children and people's health, for nonviolence and peace (Eisler, 2007). But according to the current status of Sri Lankan economic and social perspective, nations need to move towards a better place than existing which provides clear evidences on both theoretical and practical aspects of current economic and social indicators and a real time need has be arise to be change in terms of achieving a better living conditions all over the world.

At present Sri Lankan economy is also facing the same scenario that numerical values shows improvements while, the economy is drag behind by an invisible hand which is difficult to identify, understand and address. Even though it is not possible to stay silence, in which this silence would severely effect on the future generation of the nations. With the empathy, responsibility and concern for human welfare, optimal human development should be encourage within nations and this can be defined as caring economics. Shifting to a caring economics will take longer time. It will require changes in both cultural values and social institutions (Eisler, 2013). This approach need to be start from the school education, the fundamental level which is the skim of each generation. Based on the Sri Lankan context, this gradual change should be a habitat rather than a rule, due to Sri Lankans do not have fear of breaking rules since money can replace on broken rules. 
In addition to that, awareness of ethics and responsiveness would also help to change the mind set of people of the country, in a context where all the individuals are self-thinkers rather than being sensitive to others. All have become living "Herod", who are washing out their hands from the responsibilities. Immediate remedies need to be address in order to survive in sustainable and healthy social manner in every nation. The corrective actions should be initiated by the regulatory bodies and motivate the general public towards caring and care giving approach. Therefore, change is hard at first, messy in the middle and gorgeous at the end.

\section{Acknowledgement}

This research has been supported by Ms. N. D. H. Fernando, Ms. D. S. Edirisingha and Mr. M. D. Abeyaratna, Postgraduates (MBA in Accounting and Information Management, 2016-2018 weekend batch) of Postgraduate and Mid-Career Development Unit, Faculty of Management and Finance, University of Colombo.

\section{References}

Becker, G. S. (1960). An Economic Analysis of Fertility. In U.-N. Bureau, Demographic and Economic Change in Developed Countries (pp. 209 - 240). Columbia University Press.

Bhalla, S. S., \& Glewwe, P. (1986). Growth and equity in developing countries: A reinterpretation of the Sri Lankan experience. The World Bank Economic Review, 3563. https://doi.org/10.1093/wber/1.1.35

Birchall, O. (2016). Introduction to Economics. The London School of Economics and Political Science. London: University of London.

CBSL. (2017). Statistics. Retrieved August 7, 2017, from Central Bank of Sri Lanka: http://www.cbsl.gov.lk/htm/english/08_stat/stat.html

Central Bank of Sri Lanka. (2016). Annual Report.

Eisler, R. (2007). The Real Wealth of Nations: Creating a Caring Economics. San Francisco: Berrett-Koehler Publishers. 
DOI: http://doi.org/10.4038/kjm.v6i0.7537

Eisler, R. (2013, April 7). Building a Caring Economy and Society. Beyond Capitalism, Socialism, and Other Old Isms, 2(6).

Flinn, M. V., \& England, B. G. (1997). Social economics of childhood glucocorticoid stress response and health. American Journal of Physical Anthropology, 102(1), 33-53. https://doi.org/10.1002/(SICI)1096-8644(199701)102:1<33::AID-AJPA4>3.0.CO;2-E

Ghosh, I. (2015). Caring Economics: A New Framework for Conceptualizing and Measuring Economic Activity. Creative Nursing, 21(2). https://doi.org/10.1891/1078$\underline{4535.21 .2 .80}$

Mankiw, N. G. (2015). Essentials of Economics (Seventh International Edition ed.). SouthWestern Cengage Learning.

Marmot M. G, S. D., Stansfield, S., Patel, C., North, F., Head, J., White, I., et al. (1991). Health inequalities among British civil servants: The Whitehall II study. The Lancet, 13871393. https://doi.org/10.1016/0140-6736(91)93068-K

OG Dayaratna-Banda Ph.D. (2014 July). Sustainability of Government Debt in Sri Lanka.

Rougoor, C. W., Trip, G., Huirne, R. B., \& Renkema, J. (1998). How to define and study Farmers' Management Capacity: Theory and use in Agricultural Economics. Agricultural economics, 18(3), 261-272. $\quad$ https://doi.org/10.1016/S0169$\underline{5150(98) 00021-8}$

Seligman, M. E. (2002). Authentic happiness: Using the new positive psychology to realize your potential for lasting fulfillment.

The Department of Census and Statistics. (2015, June). Sri Lanka Socio-Economic Data. Sri Lanka Socio-Economic Data - 2015, XXXVIII, p. 49.

The Department of Census and Statistics. (2016, June). Sri Lanka Socio-Economic Data. Sri Lanka Socio-Economic Data, XXXIX, pp. 50-52. 
DOI: http://doi.org/10.4038/kjm.v6i0.7537

The Department of Census and Statistics. (2017). Department of Census and Statistics - Sri Lanka. Retrieved August 1, 2017, from Statistics Government: http://www.statistics.gov.lk/

The World Bank Group. (2017, April 10). The World Bank In Sri Lanka. Retrieved from THE WORLD BANK - IBRD IDA

http://www.worldbank.org/en/country/srilanka/overview 